\title{
Expressive Writing Therapy dan Kemampuan Pengungkapan Emosi Pasien Skizofrenia Hebefrenik
}

\author{
Risna Amalia1, Tatik Meiyuntariningsih ${ }^{1}$ \\ 1Magister Psikologi Profesi Universitas 17 Agustus 1945 Surabaya
}

DOI: http://doi.org/10.29080/jpp.v11i2.378

\begin{abstract}
Hebephrenic schizophrenia suppresses normal functions such as apathy and poor social response. This study aims to test the effectiveness of expressive writing therapy interventions to improve the ability to express emotions to clients of hebephrenic schizophrenia. The subject was a male who was 45 years old and had hebephrenic schizophrenia for one year. The results of this study indicate that expressive writing therapy is effective for expressing the feelings or emotions of the subject, as well as releasing negative emotions. The follow-up plan after the intervention direct the subject able to channel their emotion and express their feelings. Also, the family expected to provide social support and keep motivating him
\end{abstract}

Keywords : Expressive Writing Therapy, Schizophrenia Hebefrenik

\begin{abstract}
Abstrak : Skizofrenia hebefrenik menekan fungsi normal seperti apatis dan aktivitas sosial yang buruk. Penelitian ini bertujuan untuk menguji efektifitas intervensi expressive writing therapy untuk meningkatkan kemampuan pengungkapan emosi kepada klien skizofrenia hebefrenik. Subjek berjenis kelamin laki-laki yang berusia 45 tahun dan mengalami skizofrenia hebrefenik selama satu tahun. Hasil dari penelitian ini menunjukkan bahwa expressive writing therapy efektif digunakan sebagai media mengungkapkan perasaan atau emosi subjek, serta pelepasan emosi negatif yang dimiliki. Rencana tindak lanjut setelah intervensi tetap diberikan, subjek diarahkan agar mampu menyalurkan emosinya dan mengungkapkan perasaannya. Selain itu keluarga diharapkan untuk terus memberikan dukungan sosial yang dibutuhkan oleh subjek dengan terus memotivasinya.
\end{abstract}

Kata kunci : Expressive Writing Therapy, Skizofrenia Hebefrenik

\section{Pendahuluan}

Kesehatan jiwa masih menjadi salah satu permasalahan kesehatan yang signifikan di dunia, termasuk di Indonesia. Menurut data WHO (2016), terdapat sekitar 35 juta orang terkena depresi, 60 juta orang terkena bipolar, 21 juta terkena skizofrenia, serta 47,5 juta terkena dimensia. Di Indonesia, dengan berbagai faktor biologis, psikologis dan sosial

Corresponding Author: Risna Amalis (e-mail: risnaamaliaa.psy@gmail.com) Program Studi Magister Psikologi Profesi Universitas 17 Agustus 1945 Surabaya, Jl. Semolowaru No.45, Menur Pumpungan, Kec. Sukolilo, Kota SBY, Jawa Timur, Indonesia 60118 
dengan keanekaragaman penduduk; maka jumlah kasus gangguan jiwa terus bertambah yang berdampak pada penambahan beban negara dan penurunan produktivitas manusia untuk jangka panjang. Prevalensi gangguan jiwa pada tahun 2018 mencapai sekitar 7\% dari total penduduk Indonesia. Data Riset Kesehatan Dasar (RISKESDAS) di Indonesia tahun 2013-2018 menujukkan bahwa prevalensi gangguan jiwa skizofrenia atau psikosis pada tahun 2013 mencapai sekitar 1,7 \% dari total penduduk Indonesia.

Riskesdas 2018 turut mencatat proporsi rumah tangga dengan minimal salah satu anggota keluarga yang mengalami gangguan jiwa skizofrenia atau psikosis yang pernah dipasung pada tahun 2013-2018 menunjukkan bahwa pada tahun 2013 orang dengan gangguan jiwa pernah dipasung mencapai sekitar 14,3\% dari total penduduk Indonesia di peekotaan maupun perdesaan. Sedangkan pada tahun 2018 orang dengan gangguan jiwa pernah dipasung mencapai sekitar 14\% dari total penduduk Indonesia di peekotaan maupun perdesaan (Riskesdas Depkes RI, 2018).

Skizofrenia adalah gangguan psikotik yang ditandai dengan gangguan utama dalam pikiran, emosi, perilaku yang terganggu. Berbagai pemikiran tidak saling berhubungan secara logis. Persepsi dan perhatian yang keliru, afek yang datar atau tidak sesuai dan berbagai gangguan aktivitas motoric yang bizarre. Pasien skizofrenia menarik diri dari orang lain dan kenyataan, sering kali masuk dalam kehidupan fantasi yang penuh delusi dan halusinasi (Davinson, 2010). Skizofrenia termasuk dalam salah satu gangguan mental yang disebut psikosis. Pasien psikotik tidak dapat mengenali atau tidak memiliki kontak dengan relaitas (Arif, 2006). Skizofrenia ditandai oleh penyimpangan yang fundamental dan karakteristik dari pikiran persepsi serta afek yang tidak wajar (Maslim 2013).

Gangguan kesehatan mental yang ditandai dengan persepsi dan perilaku yang terdistorsi atau skizofrenia memiliki dua kategori gejala yaitu positif dan negatif. Gejala positif menyebabkan kelebihan fungsi kognitif yang termasuk delusi dan halusinasi. Gejala negatif menekan fungsi normal seperti apatis dan aktivitas sosial yang buruk (Sie, 2011). Skizofrenia hebefrenik ditandai dengan adanya kemunduran perilaku dan memiliki onset aawal jika dibandingkan dengan tipe lainnya. Individu yang mengalami skizofrenia hebefrenik akan menunjukkan perilaku aneh, kekanak-kanakan, bertingkah konyol, tertawa dangkal, asosiasi longgar, sedangkan delusi maupun halusinasi tidak tampak menonjol. Gejala lain yang bisa muncul adalah perilaku tanpa alasan dan tanpa tujuan, seperti berjalan tanpa tujuan. Terkadang sikap menarik diri juga muncul pada tipe ini. Beberapa juga menunjukkan gejala asosiasi longgar dan inkoherensi (Eddy, 2017).

Menurut Ibrahim (2011), tipe skizofrenia hebefrenik seringkali ditandai dengan adanya regresi yang dapat dilihat secara langsung, munculnya perilaku-perilaku primitive dan perilaku yang tidak teratur. Penderita skizofrenia hebrefenik seringkali terlihat aktif, tertawa tanpa alasan, menyeringai, akan tetapi perilakunya tidak konstruktif dan tampak tidak memiliki tujuan. Isi pikir dan arus pikirnya sangat terdisorganisasi, terlihat sangat menonjol dan kemampuan kontak dengan kenyataan cenderung buruk. Sangat disaayangkan jika usia produktif yang seharusnya digunakan untuk belajar, memulai bekerja, mempersiapkan pernikahan, dan menjalankan peran lainnya ternyata terhambat karena gejala-gejala dari gangguan skizofrenia. Tipe hebefrenik menurut Eddy (2017), seringkali disebut sebagai tipe dengan prognosis yang buruk jika dibandingkan dengan tipe lainnya. Kondisi tersebut tentunya menjadi salah satu faktor dibutuhkannya penanganan yang tepat agar gejala tidak berkembang lebih buruk sehingga dapat meningkatkan prognosis.

Diagnosis Skizofrenia Hebefrenik berdasarkan PPDG memenuhi kriteria umum diagnosis Skizofrenia, dan ditegakkan pada usia remaja atau dewasa muda (15-25 tahun). Kepribadian premorbid menunjukkan ciri khas seperti pemalu dan senang menyendiri . Pengamatan secara kontinu perlu dilakukan selama 2-3 bulan untuk memastikan bahwa gambaran yang teramati benar bertahan. Adapun perilaku tidak bertanggung jawab dan 
tidak dapat diramalkan, kecenderungan untuk menyendiri dan perilaku menunjukkan hampa tujuan dan hampa perasaan. Afek dangkal dan tidak wajar, di sertai cekikikan atau perasaan puas diri, senyum sendiri, tertawa menyeringai, mengibuli secara bersenda gurau, keluhan hipokondriakal dan ungkapan kata yang di ulang-ulang.

Proses pikir mengalami disorganisasi dan pembicaraan tak menentu serta inkoheren. Gangguan afektif dan dorongan kehendak, serta gangguan proses pikir umumnya menonjol Halusinasi dan waham mungkin ada tetapi tidak menonjol. Dorongan kehendak dan yang bertujuan hilang serta sasaran ditinggalkan, sehingga perilaku penderita memperlihatkan ciri khas, yaitu perilaku tanpa tujuan dan tanpa maksud. Adanya suatu preokupasi yang dangkal dan bersifat dibuat-buat terhadap agama, filsafat, dan tema abstrak sehingga mempersukar orang lain memahami jalan pikiran pasien (Maslim,2013).

Peneliti menggunakan expressive writing therapy sebagai media untuk meningkatkan kemampuan pengungkapan emosi dengan alasan karena subjek yang mengalami skizofrenia hebefrenik kesulitan untuk mengungkapkan perasaan yang ada di hatinya. Subjek juga kesulitan untuk bercerita atau berkomunikasi dengan orang lain. Selain itu, expressive writing therapy juga memiliki tujuan untuk memudahkan seseorang dalam mengungkapkan emosi atau mengungkapkan berbagai hal yang tidak bisa dikatakannya selama ini. Expressive Writing pertama kali dicetuskan oleh Pennebeker pada tahun 1989. Pennebeker yang merupakan seorang professor di bidang Psikologi Sosial banyak meneliti manfaat dari kegiatan menulis. Pada awal penelitiannya, Pennbeker meneliti manfaat menulis pada klien dengan gangguan Post Traumatic and Stress Disorder. Kemudian Pennebeker memperluas penemuannya dengan melakukan eksperimen bidang psikososial, yaitu mengenai relasi sosial dan hubungan romantis (Sindiro, 2006).

Expressive Writing merupakan sebuah proses terapi dengan menggunakan metode menulis ekspresif untuk mengungkapkan pengalaman emosional dan mengurangi stress yang dirasakan individu sehingga dapat membantu memperbaiki kesehatan fisik, menjernihkan pikiran, memperbaiki perilaku dan menstabilkan emosi. Ekspresif emosional merupakan ekspresi natural dari emosi yang sebenarnya (Qanitatin, 2011).

Menurut Pennebeker (1997), expressive writing menyediakan peluang bagi individu untuk memantulkan perasaannya secara emosional dalam bentuk peningkatan penggunaan kata-kata penyampaian emosi selama interaksi sosial, peningkatan penyampaian emosi tersebut akan meningkatkan perbaikan dalam stabilitas hubungan". Expressive Writing Treatment dianggap mampu mereduksi stres karena saat individu berhasil mengeluarkan emosi-emosi negatifnya (perasaan sedih, kecewa, duka) ke dalam tulisan, individu tersebut dapat mulai merubah sikap, meningkatkan kreativitas, mengaktifkan memori, memperbaiki kinerja dan kepuasan hidup serta meningkatkan kekebalan tubuh agar terhindar dari psikosomatik.

Penelitian yang dilakukan oleh Reyza Dahlia Murti dan Hamidah (2012) yang berjudul pengaruh expressive writing terhadap penurunan depresi pada remaja SMK di Surabaya menunjukkan bahwa tidak ada pengaruh yang signifikan expressive writing terhadap penurunan depresi pada remaja SMK di Surabaya. Temuan lain dalam penelitian ini yaitu depresi sedang merupakan tingkatan depresi yang paling banyak dialami oleh remaja kelas X di SMK Kawung 1 Surabaya, remaja laki-laki dan perempuan yang menjadi siswa kelas X di SMK Kawung 1 Surabaya memiliki presentase yang hampir sama pada setiap tingkatan depresi, expressive writing dapat menurunkan depresi jika semakin banyak kata-kata beremosi positif dan kata-kata kognitif pada hari terakhir menulis, katakata beremosi negatif dalam jumlah sedang, alur cerita yang jelas dan terorganisir dengan baik, serta adanya pandangan dan harapan yang positif.

Penelitian yang dilakukan oleh Susanti dan Supriyantini (2013) yang berjudul pengaruh expressive writing therapy terhadap penurunan tingkat kecemasan berbicara di 
muka umum pada mahasiswa menyatakan bahwa terdapat penurunan yang signifikan tingkat kecemasan berbicara di muka umum pada kelompok eksperimen setelah diberi perlakuan expressive writing therapy. Berdasarkan analisa kualitatif terhadap hasil observasi, wawancara dan kuesioner disimpulkan adanya peningkatan kepercayaan diri, self esteem, dan positive self talk Expressive writing therapy dapat digunakan sebagai terapi alternatif bagi permasalahan psikologis yang mempengaruhi kondisi fisiologis, kognitif dan emosional individu.

Penelitian yang dilakukan oleh Diah Widyawati Retnoningtyas, AA Gede Agung Angga Atmaja, AA Intan Pratiwi, Kadek Dilan Ari Rahayu (2017) yang berjudul pengaruh expressive writing terhadap penurunan tingkat kecemasan mahasiswa tahun pertama menunjukkan bahwa ada penurunan kecemasan pada kelompok eksperimen dan perbedaan yang signifikan antara kelompok yang tidak menerima perlakuan dan kelompok partisipan yang melakukan expressive writing. Penelitian yang dilakukan oleh Laila Faried, IGAA Noviekayati, Sahat Saragih (2018) yang berjudul efektivitas pemberian expressive writing therapy terhadap kecenderungan self injury ditinjau dari tipe kepribadian introvert menunjukkan bahwa ada pengaruh pemberian expressive writing therapy terhadap kecenderungan self injury pada remaja setelah diberikannya perlakuan atau terapi. Hal ini menunjukkan kecenderungan self injury pada remaja dapat diturunkan dengan menggunakan expressive writing therapy yang berarti expressive writing therapy cukup efektif dalam menurunkan kecenderungan self injury pada remaja.

Solusi untuk membantu individu dengan skizofrenia hebefrenik masih perlu terus dilakukan agar memberikan mereka kemampuan mengontrol diri. Jika para penderita Skizofrenia hebefrenik tidak dibantu maka kondisi mereka akan terus bertambah buruk dan akan mempengaruhi lingkungan sekitarnya. Ada sejumlah penelitian sebelumnya yang melihat penggunaan expressive writing sebagai terapi namun pada penelitian ini berbeda subjek yang akan diterapi. Penelitian ini akan membahas tentang penerapan expressive writing therapy untuk meningkatkan kemampuan pengungkapan emosi pada pasien skizofrenia hebefrenik di RSJ Dr. Radjiman Wediodiningrat Malang.

\section{Metode Penelitian}

Penelitian ini menggunakan metode kualitatif dengan jenis pendekatan studi kasus. Penelitian ini menggunakan single subjek berinisial KA, berjenis kelamin laki-laki dan berusia 45 tahun. Subjek memiliki beberapa gejala yaitu, merusak barang ketika emosi tidak mampu dikontrol, afek datar, hampa perasaan dan suka menyendiri. Subjek juga memiliki masalah dalam menjalin hubungan interpersonal serta menunjukkan perilaku gaduh gelisah berupa berjalan mondar mandir sambil mengusap kepala. Subjek merasa ada gangguan pada pikirannya seperti adanya waham berupa kepercayaan bahwa dirinya adalah spiderman. Dari studi dokumentasi serta hasil asesmen yang dilakukan oleh peneliti, subjek didiagnosa mengalami gangguan skizofrenia hebefrenik selama satu tahun.

Teknik pengambilan data menggunakan expressive writing therapy sebagai media untuk meningkatkan kemampuan pengungkapan emosi. Subjek diharapkan mampu untuk mengekspresikan perasaan yang terpendam, mampu untuk mengungkapkan isi hati atau keinginan-keinginannya serta pengalaman di masa lalu dengan menuliskannya di kertas. Ada beberapa tahap yang dilakukan dalam teknik ini, yang dijelaskan sebagai berikut. Rincian dan aplikasi expressive writing therapy dari Hynes dan Hynes, dan Thompson (dalam Susanti, 2013) membagi expressive writing therapy ke dalam empat tahap yakni recognation/initial writing, examination/writing exercise, juxtaposition/feedback, dan application to the self. Tahap recognation/initial writing adalah tahap pembuka yang bertujuan membangun kenyamanan sekaligus juga menulis. Tahap ini membuka imajinasi, memfokuskan pikiran, relaksasi dan menghilangkan ketakutan yang mungkin muncul 
pada diri subjek, serta mengevaluasi kondisi mood atau konsentrasi subjek. Subjek diberi kesempatan untuk menulis dengan bebas kata-kata, frase, atau mengungkapkan hal lain yang muncul dalam pikiran tanpa perencanaan dan arahan.

Pada tahap kedua yaitu examination/writing exercise proses menulis mulai dilakukan. Tahapan ini bertujuan untuk mengeksplorasi reaksi subjek terhadap suatu situasi tertentu. Juxtaposition/feedback adalah tahap ketiga yang merupakan sarana refleksi yang mendorong pemerolehan kesadaran baru yang menginspirasi perilaku, sikap, nilai yang baru serta membuat individu memperoleh pemahaman yang lebih dalam tentang dirinya. Tulisan yang sudah dibuat subjek, direfleksikan atau dikembangkan, disempurnakan dan didiskusikan bersama. Pada tahap ini subjek mendapatkan pengetahuan baru kemudian diaplikasikan dan berlanjut pada kesepakatan antara subjek dengan peneliti atas perubahan tingkah laku yang akan dilakukan di kemudian hari. Application to the self adalah tahap terakhir dari terapi expressive writing dimana pada tahap ini subjek didorong untuk mengaplikasikan pengetahuan barunya dalam dunia nyata. Konselor atau terapis membantu subjek mengintegrasikan apa yang telah dipelajari selama sesi menulis dengan merefleksikan kembali apa yang mesti diubah dan diperbaiki dan mana yang perlu dipertahankan, selain itu juga dilakukan refleksi tentang manfaat menulis bagi subjek.

\section{Hasil Penelitian}

Intervensi dalam penelitian ini dilakukan selama satu minggu dengan rincian enam sesi dan masing-masing 90 menit setiap sesinya.

Tabel 1.

Hasil Intervensi

\begin{tabular}{lll}
\hline \multicolumn{1}{c}{ Tahapan } & \multicolumn{1}{c}{ Sebelum Intervensi } & \multicolumn{1}{c}{ Setelah Intervensi } \\
\hline $\begin{array}{l}\text { Sesi 1 } \\
\text { Building Rapport }\end{array}$ & Klien kurang bersedia untuk & Rapport antara klien dan praktikan sudah \\
& mengungkapkan apa yang selama ini ia & terbangun dengan baik sejak pertemuan ke 5 \\
& membirkan dan lakukan. Klien & saat pelaksanaan psikotes, sehingga ia tidak \\
& untuk lebih terbuka pada praktikan. & canggung atau tidak lagi menutupi masalahnya \\
& & dari praktikan. KA lebih terbuka dengan \\
& &
\end{tabular}

Sesi $2 \quad$ Klien belum mengetahui jadwal

Penetapan Tujuan dilakukannya intervensi dan apa yang akan dilakukan selama intervensi.
Sesi 3

Pengungkapan

pikiran-pikiran

yang dimiliki

(menulis bebas)
Klien tidak mampu mengungkapkan apa yang ingin ia sampaikan.
1. Praktikan dan klien telah menetapkan tujuan intervensi agar klien memahami alur intervensi yang akan dilakukan serta memiliki komitmen selama pelaksanaan intervensi.

2. Klien menyetujui untuk dilakukannya intervensi beberapa hari ke depan, klien dan praktikan menetapkan pelaksanaan intervensi selama 4 hari pada hari selasa, kamis, jumat dan minggu.

3. Klien memahami alur berjalannya intervensi yang akan dilakukan yakni Expressive Writing Theraphy dengan 3 tahap menulis, menulis bebas, menulis pengalaman tidak menyenangkan di masa lalu, serta menulis harapan dan cita-cita.

Pada saat SMA klien diajak ayahnya ke RS Dr. Soetomo untuk memeriksakan dirinya di poli jiwa. Ayah klien membawanya ke RS Dr. Soetomo karena klien sering menyendiri di kamar dan jarang berinteraksi dengan orang lain.

Pada saat itu klien merasa marah, namun klien 


\author{
Sesi 4 \\ Pengungkapan \\ pikiran-pikiran \\ yang dimiliki \\ (menulis \\ pengalaman di \\ masa lalu yang \\ tidak \\ menyenangkan)
}

Klien tidak mampu mengungkapkan

apa yang ingin ia sampaikan.

\author{
Sesi 5 \\ Pengungkapan \\ pikiran-pikiran \\ yang dimiliki \\ (menulis harapan \\ dan cita-cita)
}

\author{
hanya bisa diam dan memendam perasaan \\ marahnya. \\ Pada tahap ini klien mampu mengungkapkan \\ perasaan marah pada ayahnya. Klien \\ menyadari bahwa ayahnya melakukan hal \\ tersebut karena ayahnya merasa khawatir atas \\ perilaku klien yang sering menyendiri di \\ kamar. Klien bersedia memaafkan kesalahan \\ yang telah dilakukan oleh ayahnya.
}

Ketika klien SD, ia sering mendapatkan kekerasan fisik dari ibunya. Ibu klien memukul punggung klien dengan gagang sapu karena klien telah mencuri tebu milik tetangganya. Klien merasa marah dan kesakitan karena dipukul, namun klien hanya bisa diam dan tidak mengatakan apapun pada ibunya. Pada tahap ini klien mampu mengungkapkan perasaan marah pada ibunya. Klien mulai memahami dan menjadikan pengalaman masa lalunya sebagai pelajaran hidup untuk lebih baik.

Klien mampu mengungkapkan isi hatinya atau perasaannya tentang harapan-harapan dan perubahan yang akan ia lakukan setelah keluar dari RSJ.

Klien ingin kembali bekerja sebagai pencari cacing sutra. Klien ingin lebih terbuka pada orang lain, serta mampu mengungkapkan apa yang ia pikirkan dan rasakan.

Klien mampu mengekspresikan perasaannya pada orang lain, seperti perasaan marah, bahagia, sedih.

\section{Pembahasan}

Jenis intervensi yang digunakan adalah Expressive writing. Istilah menulis ekspresif menurut beberapa sumber menyebutkan bahwa menulis ekpresif berarti menuliskan perasaan-perasaan dalam dirinya ke dalam sebuah buku dengan cara menceritakan atau naratif. Mekanisme dari proses terapeutik menulis ekspresif ini berorientasi pada penyingkapan (disclosure) pengalaman-pengalaman emosional. Pengakuan dan penyingkapan diri merupakan proses dasar yang muncul dalam psikoterapi, dan secara ilmiah muncul dalam interaksi sosial yang dianggap manfaat secara psikologis fisik. Penyingkapan masalah pribadi memiliki nilai terapeutik yang menakjubkan pada dirinya sendiri.

Tujuan expressive writing therapy ini diharapkan subjek mampu menuliskan apa yang ia inginkan atau ia pendam selama ini. Tulisan tersebut berisi tentang tulisan bebas, pengalaman menyedihkan serta cita-cita, impian atau keinginan subjek. Expressive writing therapy diartikan sebagai kemampuan untuk menggambarkan perasaan/isi hati/emosi dengan tepat. Terapi ini bisa membantu subjek supaya lebih mampu mengungkapkan perasaan yang selama ini dipendam.

Menurut Pennebaker dan Chung (2007) menulis ekspresif memiliki beberapa tujuan, yaitu membantu menyalurkan ide, perasaan dan harapan subjek ke dalam suatu media yang bertahan lama dan membuatnya merasa aman. Selain itu mehulis ekspresif juga membantu subjek memberikan respon yang sesuai dengan stimulusnya sehingga 
subyek tidak membuang waktu dan energi untuk menekan perasaannya. Terakhir menulis ekspresif dapat membantu subjek mengurangi tekanan yang dirasakannya sehingga membantunya mereduksi stress.

Dari enam sesi yang telah dilakukan oleh subjek, terlihat expressive writing therapy mampu meningkatkan kemampuan pengungkapan emosi. Hal tersebut tidak terlepas dari tahapan intervensi yang dirancang atau diberikan untuk subjek. Expressive Writing Treatment mampu mereduksi stres karena saat individu berhasil mengeluarkan emosiemosi negatifnya (perasaan sedih, kecewa, duka) ke dalam tulisan, individu tersebut dapat mulai merubah sikap, meningkatkan kreativitas, mengaktifkan memori, memperbaiki kinerja dan kepuasan hidup serta meningkatkan kekebalan tubuh agar terhindar dari psikosomatik.

Pada penelitian ini, expressive writing therapy cukup efektif sebagai media untuk meningkatkan kemampuan pengungkapan emosi dan perasaan yang terpendam. Hal ini bisa diketahui dari hasil sebelum dan sesudah pemberian expressive writing therapy. Sebelum diberikan terapi, subjek merasa tidak mampu mengungkapkan atau bercerita tentang apa yang dirasakan kepada orang lain. Seperti penelitian yang dilakukan oleh Laila Faried, IGAA Noviekayati, Sahat Saragih (2018) yang berjudul efektivitas pemberian expressive writing therapy terhadap kecenderungan self injury ditinjau dari tipe kepribadian introvert menunjukkan bahwa ada pengaruh pemberian expressive writing therapy terhadap kecenderungan self injury pada remaja setelah diberikannya perlakuan atau terapi. Hal ini menunjukkan kecenderungan self injury pada remaja dapat diturunkan dengan menggunakan expressive writing therapy yang berarti expressive writing therapy cukup efektif dalam menurunkan kecenderungan self injury pada remaja.

Setelah pemberian terapi, subjek merasa lebih lega karena mampu mengungkapkan dan menyampaikan emosi atau perasaan yang selama ini dipendam melalui tulisan. Subjek lebih mampu mengekspresikan emosi yang sedang dirasakannya. Ketika tahap inquiry dan refleksi, subjek mampu mengungkapkan apa yang sebenarnya ia rasakan dan meluapkan emosi-emosinya seperti perasaan marah pada ayah dan ibunya yang selama ini ia pendam. Subjek juga mampu mengungkapkan isi hati atau perasaanya tentang harapan-harapan dan perubahan yang akan ia lakukan ke depannya.

\section{Simpulan dan Saran}

Berdasarkan hasil penelitian yang telah dilakukan, dapat ditarik kesimpulan bahwa expressive writing therapy dapat digunakan sebagai media untuk meningkatkan kemampuan pengungkapan emosi atau perasaan subjek yang selama ini dipendam. Secara teoritis, expressive writing therapy adalah suatu cara atau upaya pemindahan pikiran dan perasaan yang mendalam mengenai peristiwa yang menimbulkan emosi pada seseorang ke dalam bentuk lambang bahasa melalui tulisan tangan.

Dukungan keluarga merupakan faktor utama bagi subjek karena diharapkan mampu membantu proses pemulihannya. Salah satunya dengan cara memberikan perhatian yang cukup kepada subjek dan memberikan ia kesempatan untuk mengutarakan atau menyampaikan isi pikirannya. Ada beberapa hal yang perlu dipertimbangkan apabila melakukan expressive writing therapy yaitu tempat, waktu pelaksanaan intervensi yang kurang panjang, karakteristik dan kesediaan subjek dalam melakukan proses intervensi.

\section{Daftar Pustaka}

Arif, I. S. (2006) Skizofrenia. Bandung: PT Refika Aditama.

Creswell, J. W. (2017). Research design, pendekatan kualitatif, kuantitatif dan mixed. Yogyakarta: Pustaka Pelajar. 
Davinson, G. C, Neale, J. M, \& Kring, M. A. (2010). Psikologi abnormal edisis ke 9. Jakarta: Raja Grafindo Persada.

Eddy, F. N. E, Septa, T, \& Anggraini, D. I. (2017). Diagnosis dan tatalaksana skizofrenia hebefrenik putus obat dengan logorrhea. J Medula Unila. Vol 7 No.3 hal 17-21.

Faried, L., Noviekayati, I \& Saragih, S. (2018). Efektivitas pemberian expressive writing therapy terhadap kecenderungan self-injury ditinjau dari tipe kepribadian introvert. Psikovidya, 22(2).

Hasil Utama RISKESDAS 2018. Kementrian kesehatan badan penelitian dan pengambangan kesehatan.

Ibrahim, A. S. (2011). Skizofrenia spliting personality. Tangerang: Jelajah Nusa.

Maslim, R. (2013). Diagnosis gangguan jiwa (Rujukan dari PPDGJ III dan DSM 5). Jakarta: PT Nuh Jaya.

Murti, R. D., Hamidah. (2012). Pengaruh expressive writing terhadap penurunan depresi pada remaja smk di surabaya. Jurnal Psikologi Klinis dan Kesehatan Mental, Vol 1 No. 2 .

Pennebeker, J W. (1997). Writing about emotional experiences as a therapeutic process psychological science, 8.

Qanitatin dkk. (2015). Pengaruh katarsis dalam menulis ekspresif sebagai intervensi depresi ringan pada mahasiswa. Jurnal Psikologi UNDIP vol. 9, No. 1.

Retnoningtyas, D. D., Atmaja, G. A. A., Pratiwi, I., Rahayu, K. D. A. (2017). Pengaruh expressive writing terhadap penurunan tingkat kecemasan mahasiswa tahun pertama. Jurnal Psikologi "Mandala", Vol 1 No. 1, 14-25.

Sie, M. (2011). Schizophrenia clinical features and diagnosis. Clin Pharm.

Sindiro, L F. (2016). Efektivitas expressive wrting sebagai reduktor psychological distress. Yogyakarta: Universitas Sanata Dharma.

Susanti, R. Supriyantini, S. (2013). Pengaruh expressive writing therapy terhadap penurunan tingkat kecemasan berbicara di muka umum pada mahasiswa. Jurnal Psikologi, Vol 9 No. 2. 